\title{
Herbicide efficacy on three annual grass weeds in soils with different cropping histories
}

\author{
A. Rahman and T.K. James \\ AgResearch, Ruakura Research Centre, Private Bag 3123, Hamilton 3240, New Zealand \\ Corresponding author: anis.rahman@agresearch.co.nz
}

\begin{abstract}
The efficacy of several pre-emergence herbicides on barnyard grass (Echinochloa crus-galli), smooth witchgrass (Panicum dichotomiflorum) and yellow bristle grass (Setaria pumila) was investigated in different soils in pot experiments. These soils were collected from the top $10 \mathrm{~cm}$ of seven maize fields with different cropping histories. The herbicides used were dimethanamid, alachlor, metolachlor, two formulations of acetochlor and proprietary mixes of acetochlor with atrazine or metribuzin. Plastic pots filled with soil were seeded with 10 seeds of individual grass species, and herbicide treatments were then applied with a precision pot sprayer. A further 10 seeds of the same grass species were sown at 2-weekly intervals for 8 weeks to test the duration of residual weed control. The number of emerged seedlings was counted in each pot at 2 weeks after each planting. Metolachlor was the most effective chemical for controlling E. crus-galli and P. dichotomiflorum. For S. pumila, similar levels of control were achieved by all treatments evaluated. Generally, all the herbicides were less effective in soils with a long history of maize growing where up to three times more seedlings emerged than in soils with only 1-2 years of maize cropping.
\end{abstract}

Keywords Echinochloa crus-galli, Panicum dichotomiflorum, Setaria pumila, grass weeds, chemical control, herbicide efficacy, enhanced degradation, maize.

\section{INTRODUCTION}

Barnyard grass (Echinochloa crus-galli), smooth witchgrass (Panicum dichotomiflorum) and yellow bristle grass (Setaria pumila) are among the major problem weeds in maize, sweet corn and many vegetable crops. Weed competition is among the major factors affecting maize (Zea mays) production in New Zealand. Grass weeds generally compete strongly with the maize crop and therefore failure to adequately control them is more likely to lead to yield losses. Control of annual grass weeds is becoming more difficult for New Zealand maize and sweet corn growers with the increasingly widespread occurrence of new species such as broom corn millet (Panicum miliaceum) and yellow bristle grass.

The grass weeds evaluated in this study all have a $\mathrm{C}_{4}$ photosynthetic pathway and tend to germinate throughout the summer as temperature and moisture thresholds are attained. This staggered emergence can be a serious problem as the residual activity of the herbicide used also diminishes with time. Several herbicides are currently available for control of the major annual grass weeds and these are often formulated differently by the different proprietors. There are few quantitative data available on the comparative 
efficacy of these various products on the range of grass weeds present in New Zealand maize fields. Any information from overseas on their relative efficacies will have been carried out on soils that are often different to the high organic matter soils found in New Zealand (Ahmad \& Rahman 2009).

The increasing use of post-emergence herbicides in maize crops in New Zealand indicates that the phytotoxic activity of the preemergence herbicide no longer persists for the duration of the critical weed-free period. There are several possible reasons for this but the three most plausible are: (1) with maize often planted a month earlier than it was 30 years ago, the critical weed-free period is longer due to the crop's slower growth and the pre-emergence herbicide fails to persist for the extended time, (2) the weed spectrum is changing towards more difficult-to-control weeds, especially grass weeds and (3) pre-emergence herbicides do not persist for as long in soils with a long history of maize production because of changes in the soil biology, as was discovered with EPTC + antidote over 25 years ago (Rahman \& James 1983). This project was designed to investigate the efficacy of currently available pre-emergence herbicides and their formulations on three annual grass weeds in soils with both short and long histories of maize production.

\section{MATERIALS AND METHODS}

The three grass weeds investigated in this project were barnyard grass, smooth witchgrass and yellow bristle grass. Fresh seeds obtained from plants grown in the glasshouse the previous summer were used, with no pre-conditioning. Seeds were stored at ambient temperature in sealed containers over winter and used in the experiments that were carried out between December and March.

Soils for this study came from seven maize fields with different cropping histories. These were obtained from Waikato, Bay of Plenty and Poverty Bay regions and were paired from the same farm for short (first or second year in maize) or long (more than 10 years) histories of maize production. The Waikato soil was an
Otorohanga silt loam (4.5\% organic carbon); the Bay of Plenty soil was a Ohinepanea loamy sand (3.0\% organic carbon); and the Poverty Bay soil was a Kaiti silt loam (2.5\% organic carbon). A high organic matter, peat-based soil with a long history of maize (Kaipaki silt loam, $21 \%$ organic carbon) from Waikato was also included in the study. Soil from these sites was collected in bulk from the top $10 \mathrm{~cm}$ in autumn and stored over winter in unsealed containers at room temperature until used. The herbicides evaluated included two formulations of acetochlor (Roustabout ${ }^{\circledR}$ and Sylon ${ }^{\circledR} 840$ ), alachlor $\left(\right.$ Corral $\left.^{\mathrm{TM}}\right)$, metolachlor (Dual ${ }^{\circledR}$ Gold), dimethenamid (Frontier ${ }^{\circledR}$ ) and acetochlor formulated with either atrazine (Calais ${ }^{\circledR}$ ) or metribuzin $\left(\right.$ Spark $\left.^{\mathrm{TM}}\right)$. All herbicides were applied at the highest label recommended rates.

Soil was placed in $500 \mathrm{~g}$-capacity pots (except for the Kaipaki silt loam where $1.5 \mathrm{~kg}$-capacity pots were used) and the surface divided into five segments. Ten seeds of individual grass species were planted in the first segment at about $5 \mathrm{~mm}$ depth and the pre-emergence herbicide applied immediately after sowing. The herbicides were applied through a $\mathrm{CO}_{2}$ powered moving belt precision sprayer fitted with a single, evenspray TeeJet $8001 \mathrm{E}$ nozzle to apply 200 litres/ ha at $200 \mathrm{kPa}$. After treatment the pots were lightly irrigated with a sprinkler to activate the herbicide. The plants were maintained outside with sprinkler irrigation applied similarly to all pots as required.

After 2 weeks the emerged seedlings were counted and a further ten seeds were planted into the next segment. The seeds were individually pushed into the soil with a wire probe to cause minimal surface disturbance. This process was repeated every 2 weeks for up to 8 weeks after treatment. Each grass species/herbicide combination was replicated eight times except for the peat soil in the larger pots, which was replicated four times. Eight replicates of each grass species were also planted into untreated pots of each soil type on Day Zero to ascertain seed germination. The trial data were subjected to analyses of variance to separate the treatment 
means using Minitab Ver.15 and least significant differences were calculated.

\section{RESULTS AND DISCUSSION}

At 2 weeks after treatment the seed in the untreated pots had germinated well, with all species having 90-100\% germination. These pots also showed that there were very few seeds of these three grass species present in the soil seed bank. In the treated pots, very few $(<3 \%)$ smooth witchgrass and yellow bristle grass seeds emerged from the first two plantings (Weeks 0 and 2, Table 1) in any of the soils. Comparatively, more barnyard grass seedlings emerged but still

Table 1 Number of grass seedlings that emerged after each seeding in pots sprayed with one of seven herbicide treatments. Values are the mean of seven soils.

\begin{tabular}{|c|c|c|c|c|c|c|}
\hline \multirow[b]{2}{*}{ Treatment } & \multirow{2}{*}{$\begin{array}{c}\text { Rate } \\
\text { (kg ai/ha) }\end{array}$} & \multicolumn{5}{|c|}{ Weeks after treatment when seeds were sown } \\
\hline & & 0 & 2 & 4 & 6 & 8 \\
\hline & & \multicolumn{5}{|c|}{ Barnyard grass (seedlings/pot) ${ }^{1}$} \\
\hline Acetochlor (Roustabout) & 2.52 & 0.2 & 0.5 & 1.3 & 3.1 & 4.8 \\
\hline Acetochlor (Sylon) & 2.52 & 0.2 & 0.7 & 2.3 & 3.4 & 4.8 \\
\hline Alachlor & 3.36 & 0.3 & 0.8 & 2.7 & 5.2 & 4.9 \\
\hline Metolachlor & 1.92 & 0 & 0 & 0.3 & 3.0 & 4.2 \\
\hline Dimethenamid & 1.80 & 0 & 0.2 & 2.5 & 5.3 & 5.1 \\
\hline Acetochlor+atrazine & $2.52+1.5$ & 0.2 & 0.8 & 1.7 & 4.3 & 5.8 \\
\hline Acetochlor+metribuzin & $2.1+0.53$ & 0.2 & 0.9 & 2.0 & 3.9 & 4.6 \\
\hline \multirow[t]{2}{*}{ LSD $(P=0.05)$} & & 0.31 & 0.52 & 0.78 & 1.03 & 0.86 \\
\hline & & \multicolumn{5}{|c|}{ Smooth witchgrass (seedlings/pot) ${ }^{1}$} \\
\hline Acetochlor (Roustabout) & 2.52 & 0.1 & 0.1 & 0.9 & 1.3 & 2.5 \\
\hline Acetochlor (Sylon) & 2.52 & 0.1 & 0.3 & 0.9 & 1.2 & 3.1 \\
\hline Alachlor & 3.36 & 0 & 0.3 & 0.6 & 1.0 & 2.2 \\
\hline Metolachlor & 1.92 & 0 & 0.1 & 0.3 & 1.5 & 2.4 \\
\hline Dimethenamid & 1.80 & 0.1 & 0.3 & 0.9 & 1.7 & 3.0 \\
\hline Acetochlor+atrazine & $2.52+1.5$ & 0.1 & 0.2 & 1.1 & 2.0 & 4.4 \\
\hline Acetochlor+metribuzin & $2.1+0.53$ & 0.1 & 0.1 & 0.6 & 1.5 & 2.9 \\
\hline \multirow[t]{2}{*}{$\operatorname{LSD}(\mathrm{P}=0.05)$} & & 0.12 & 0.33 & 0.64 & 0.49 & 1.14 \\
\hline & & \multicolumn{5}{|c|}{ Yellow bristle grass (seedlings/pot) ${ }^{1}$} \\
\hline Acetochlor (Roustabout) & 2.52 & 0 & 0 & 1.2 & 3.5 & 4.9 \\
\hline Acetochlor (Sylon) & 2.52 & 0 & 0 & 1.0 & 3.5 & 4.9 \\
\hline Alachlor & 3.36 & 0 & 0.1 & 1.7 & 4.1 & 6.3 \\
\hline Metolachlor & 1.92 & 0 & 0 & 1.2 & 3.3 & 3.9 \\
\hline Dimethenamid & 1.80 & 0 & 0.1 & 1.7 & 4.5 & 6.0 \\
\hline Acetochlor+atrazine & $2.52+1.5$ & 0 & 0 & 2.0 & 4.4 & 6.5 \\
\hline Acetochlor+metribuzin & $2.1+0.53$ & 0 & 0 & 1.3 & 3.1 & 5.2 \\
\hline $\operatorname{LSD}(\mathrm{P}=0.05)$ & & 0.02 & 0.15 & 0.63 & 0.89 & 1.21 \\
\hline
\end{tabular}

${ }^{1}$ Average seedling numbers in untreated were: barnyard grass 10.0, smooth witchgrass 10.0 and yellow bristle grass 9.8 seedlings/pot. 
generally less than $10 \%$ of that planted. Seedling emergence from the 4-week planting was still below $15 \%$ for smooth witchgrass, and below $20 \%$ for yellow bristle grass (Table 1). At this stage there were generally fewer seedlings in the pots treated with metolachlor than in any other treatment and the emergence of barnyard grass was greater than that of the other two grasses.

For all the three grasses, differences that were significant at the 4 -week planting were often not significant at the 6 -week planting. Up to 6 weeks of residual weed control has previously been reported as the expected norm from preemergence herbicides in maize in New Zealand (Rahman \& James 1994). This was barely achieved in the present study, with up to $53 \%$ of the seed planted at this time emerging. Again there were fewer seedlings in the pots treated with metolachlor, although the differences were significant only in the case of barnyard grass (Table1). Overall, smooth witchgrass was best controlled by all the herbicides (with least number of seedlings emerging at 6 weeks) and barnyard grass was the least controlled species, at least by some of the herbicides (Table 1).

By Week 8 the number of seedlings emerged in most treatments was around $50 \%$ or more for yellow bristle grass, except for metolachlor, which was still giving significantly better control compared to other herbicide treatments. Most of the treatments showed a marked increase in the number of seedlings emerged from the 6-week planting to the 8 -week planting (Table 1). Smooth witchgrass was the best controlled species at Week 8 , with only one third or less of the seed emerging in most treatments (Table 1). Of the herbicides investigated, overall metolachlor exhibited the best efficacy on these grass weeds. Dimethenamid often showed lower efficacy than the other products evaluated here (Table 1).

Significant differences were recorded in the efficacy of various herbicides between the different soils. These differences were most noticeable with yellow bristle grass. Differences between the soils were most obvious in the emergence of seedlings from the 6-week planting. Therefore only data from this planting are presented here (Table 2).
Overall, soil organic carbon content appeared to have little influence on the activity of the various herbicides, with their activity in the high organic carbon Kaipaki silt loam being as good as or better than that of the other soils with considerably lower organic carbon content. This contrasts with the common expectation of reduced herbicidal activity in soils with high organic carbon content (Rahman \& James 2002). However, Rahman et al. (1976) showed that the chloroacetamide herbicide alachlor was sorbed to the soil less than herbicides like atrazine and trifluralin. Also, the rate of sorption was not proportional in peaty soils due to their lower bulk density.

Smooth witchgrass is a common weed of maize in all three regions from where soils were collected. Of the three species, it also has the smallest seed with a thousand seed weight of $0.75 \mathrm{~g}$ (cf. barnyard grass $2.27 \mathrm{~g}$ and yellow bristle grass $2.41 \mathrm{~g}$ ). The small size of smooth witchgrass seed appears to have made it more sensitive to the biologically active concentrations of herbicide in soil than the larger-seeded species. Thus, the differences between the soils were generally more noticeable with smooth witchgrass than with the other grass species (Table 2). However, after the 6- and 8-week plantings more smooth witchgrass emerged than the two larger seeded species and the differences between the soils were less accentuated.

Generally all herbicides, except metolachlor, exhibited reduced phytotoxicity in the soils with a long history of maize growing, where up to three times more seedlings emerged than in soils with a short cropping history (Table 2). Similar results were reported by James \& Rahman (2009) on three other annual grasses using the same field soils. It is difficult to explain these differences in terms of soil properties and the best explanation appears to be that of enhanced microbial degradation (Krutz et al. 2007). Krutz et al. (2008) noted that soils with a long history of using particular herbicides also tend to have the ability to break down those and related herbicides more rapidly. This could also explain why the combination products evaluated in this study had reduced efficacy in the soils with a 
long history of maize growing, as few of these fields would have previous exposure to metribuzin but would have been sprayed with triazine herbicides, which have a similar mode of action.
In view of the experience of New Zealand maize growers in the 1980s where repeated applications of the herbicide EPTC over a 5-year period led to its enhanced degradation and

Table 2 Number of grass seedlings that emerged in each soil type (with short or long maize-growing history) after the 6-week seeding of the pots sprayed with one of seven herbicide treatments.

\begin{tabular}{|c|c|c|c|c|c|c|c|}
\hline \multirow[b]{3}{*}{ Treatment } & \multicolumn{7}{|c|}{ Soil type ${ }^{1}$} \\
\hline & \multicolumn{2}{|c|}{ Otorohanga } & \multicolumn{2}{|c|}{ Kaiti } & \multicolumn{2}{|c|}{ Ohinepanea } & \multirow{2}{*}{$\begin{array}{c}\text { Kaipaki } \\
\text { Long }\end{array}$} \\
\hline & Short & Long & Short & Long & Short & Long & \\
\hline & \multicolumn{7}{|c|}{ Barnyard grass (seedlings/pot) ${ }^{2}$} \\
\hline Acetochlor (Roustabout) & 5.3 & 5.4 & 3.4 & 5.3 & 2.9 & 7.4 & 2.8 \\
\hline Acetochlor (Sylon) & 2.9 & 4.5 & 6.0 & 6.6 & 4.1 & 6.0 & 2.5 \\
\hline Alachlor & 5.0 & 4.4 & 2.0 & 5.9 & 4.5 & 8.9 & 2.8 \\
\hline Metolachlor & 4.5 & 4.1 & 2.8 & 5.4 & 3.4 & 6.3 & 2.3 \\
\hline Dimethenamid & 3.1 & 4.8 & 2.8 & 7.5 & 5.4 & 9.4 & 1.0 \\
\hline Acetochlor+atrazine & 3.6 & 6.5 & 3.8 & 7.4 & 7.0 & 7.8 & 3.3 \\
\hline Acetochlor + metribuzin & 2.8 & 5.4 & 2.9 & 5.4 & 4.8 & 5.9 & 5.5 \\
\hline \multirow[t]{2}{*}{$\operatorname{LSD}(\mathrm{P}=0.05)$} & \multicolumn{7}{|c|}{1.98 - applies to both rows and columns } \\
\hline & \multicolumn{7}{|c|}{ Smooth witchgrass (seedlings/pot) ${ }^{2}$} \\
\hline Acetochlor (Roustabout) & 1.4 & 3.3 & 3.0 & 2.6 & 0.9 & 3.4 & 3.3 \\
\hline Acetochlor (Sylon) & 2.5 & 2.9 & 1.5 & 2.1 & 4.4 & 5.9 & 2.0 \\
\hline Alachlor & 2.4 & 2.4 & 2.1 & 1.0 & 2.1 & 3.9 & 0.3 \\
\hline Metolachlor & 1.0 & 1.9 & 2.0 & 1.4 & 5.5 & 3.8 & 0.8 \\
\hline Dimethenamid & 2.4 & 2.3 & 1.9 & 3.0 & 3.6 & 5.4 & 1.5 \\
\hline Acetochlor+atrazine & 1.1 & 2.3 & 1.6 & 2.9 & 4.8 & 6.0 & 1.8 \\
\hline Acetochlor+metribuzin & 3.8 & 3.1 & 2.1 & 2.5 & 3.3 & 3.0 & 2.3 \\
\hline \multirow[t]{2}{*}{$\operatorname{LSD}(\mathrm{P}=0.05)$} & \multicolumn{7}{|c|}{1.05 - applies to both rows and columns } \\
\hline & \multicolumn{7}{|c|}{ Yellow bristle grass (seedlings/pot) ${ }^{2}$} \\
\hline Acetochlor (Roustabout) & 5.1 & 7.3 & 2.1 & 4.4 & 5.3 & 7.8 & 0.5 \\
\hline Acetochlor (Sylon) & 4.3 & 5.8 & 2.8 & 4.5 & 5.8 & 9.1 & 0.0 \\
\hline Alachlor & 5.9 & 9.4 & 2.0 & 5.8 & 7.5 & 9.1 & 3.0 \\
\hline Metolachlor & 1.8 & 5.3 & 0.4 & 2.4 & 6.4 & 7.4 & 3.5 \\
\hline Dimethenamid & 6.1 & 8.8 & 1.8 & 3.6 & 9.3 & 9.1 & 0.5 \\
\hline Acetochlor+atrazine & 5.1 & 8.5 & 1.9 & 4.5 & 8.0 & 9.3 & 4.3 \\
\hline Acetochlor+metribuzin & 2.1 & 7.5 & 1.4 & 3.3 & 9.6 & 9.4 & 1.3 \\
\hline $\operatorname{LSD}(\mathrm{P}=0.05)$ & \multicolumn{7}{|c|}{$2.16-$ applies to both rows and columns } \\
\hline
\end{tabular}

${ }^{1}$ Soil types: Short $=$ short term and Long $=$ long term maize growing.

${ }^{2}$ Average seedling numbers in untreated were: barnyard grass 10.0, smooth witchgrass 10.0 and yellow bristle grass 9.8 seedlings/pot. 
failure to control weeds (Lee et al. 1984), similar phenomena cannot be ruled out with other preemergence herbicides in New Zealand's high organic matter soils. Although EPTC was effective in controlling both grass and broadleaf weeds, there were other options available to replace this herbicide. Currently in New Zealand most of the maize crop is treated with either acetochlor alone or in combination with atrazine and if either or both of these herbicides were to become ineffective due to enhanced degradation, there are few options available for effective control of many weeds. This would be particularly so if the enhanced degradation also occurs with other chemically related herbicides (Krutz et al. 2008). Enhanced degradation has already been reported from laboratory studies with both nicosulfuron and atrazine in a Horotiu silt loam soil from the Waikato (James 2008). An evaluation of enhanced degradation in seven soils with a long history of maize production is currently underway, involving detailed laboratory and field investigations.

\section{ACKNOWLEDGEMENTS}

Thanks are due to the MAF Sustainable Farming Fund and the Foundation for Arable Research for funding this project. Nick Pett and Sarah Keatley, B.Sc.Tech students from Waikato University, provided considerable technical assistance.

\section{REFERENCES}

Ahmad R, Rahman A 2009. Sorption characteristics of atrazine and imazethapyr in soils of New Zealand: Importance of independently determined sorption data. Journal of Agricultural and Food Chemistry 57: 10866-10875.

James TK 2008. Characterisation of herbicide behaviour in some innovative growing media. PhD Thesis, Massey University, Palmerston North, New Zealand. 227 p.
James TK, Rahman A 2009. Efficacy of preemergence herbicides on three annual grass weeds in different soils. New Zealand Plant Protection 62: 356-362.

Krutz LJ, Burke IC, Reddy KN, Zablotowicz RM 2008. Evidence for cross-adaptation between $s$-triazine herbicides resulting in reduced efficacy under field conditions. Pest Management Science 64: 1024-1030.

Krutz LJ, Zablotowicz RM, Reddy KN, Koger $\mathrm{CH}$, Weaver MA 2007. Enhanced degradation of atrazine under field conditions correlates with loss of weed control in the glasshouse. Pest Management Science 63: 23-31.

Lee A, Rahman A, Holland PT 1984. Decomposition of the herbicide EPTC in soils with a history of previous EPTC applications. New Zealand Journal of Agricultural Research 27: 201-206.

Rahman A, Burney B, Whitham JM, Manson BE 1976. A comparison of the activity of herbicides in peat and mineral soils. New Zealand Journal of Experimental Agriculture 4: 79-84.

Rahman A, James TK 1983. Decreased activity of EPTC + R-25788 following repeated use in some New Zealand soils. Weed Science 31: 783-789.

Rahman A, James TK 1994. Field persistence of some maize herbicides in two soils. Proceedings of the 47th New Zealand Plant Protection Conference: 6-10.

Rahman A, James TK 2002. Minimising environmental contamination by selecting appropriate herbicide dose. In: Kookana RS, Sadler R, Sethunathan N, Naidu R ed. Environmental Protection and Risk Assessment of Organic Contaminants. Science Publishers Inc., Enfield, NH, USA [ISBN 1-57808-193-9]. Pp. 209-224. 